\title{
Comparison of Protective Effect of Apium graveolens and Aloe vera Supplemented with Zinc on Cadmium Induced Hepato and Nephro-Toxicity in Wistar Rats
}

\author{
Sushanth N.K. ${ }^{1}$, Vijayaraghavan R. ${ }^{2}$, Vijayalakshmi S. ${ }^{3}$, Senthilkumar Sivanesan ${ }^{4}$, \\ Madhan Kumar Swaminathan ${ }^{5}$, Praveen Kumar P6 \\ 1,2, 4, 5, 6 Department of Research and Development, Saveetha Institute of Medical and Technical \\ Sciences, Thandalam, Chennai, India, ${ }^{3}$ Department of Anatomy, Saveetha Institute of Medical and \\ Technical Sciences, Thandalam, Chennai, India.
}

\begin{abstract}
BACKGROUND
Cadmium (Cd) is an environmental pollutant that accumulates in various organs such as liver, kidney, and other organs. It generates reactive oxygen species, thereby resulting in pathological changes in the organs it accumulates in by depleting antioxidants. Apium graveolens (AG) and Aloe vera (AV) are rich sources of antioxidants. Zinc ( $\mathrm{Zn}$ ) is an important antioxidant trace element present in various tissues and this protects the organs from the toxic effects of cadmium. We wanted to compare the protective effect of $A G$ and $A V$ with and without $\mathrm{Zn}$ supplementation in Cd exposed liver and kidneys of Wistar rats.
\end{abstract}

\section{METHODS}

Male Wistar albino rats were divided into 11 groups. The control group received only vehicle, the experimental groups were administered with $10 \mathrm{mg} / \mathrm{Kg}$ bw of $\mathrm{CdCl}_{2}$, $40 \mathrm{mg} / \mathrm{Kg}$ bw of $\mathrm{ZnCl}_{2}, 200 \mathrm{mg} / \mathrm{Kg}$ bw of AG and AV, 400mg / K bw AG and AV separately and in combination. After 56 days, the animals were sacrificed and histopathology was done.

\section{RESULTS}

Cd resulted in significant tissue damage of liver and kidney. AG, AV and Zn were able to offer protection to these tissues.

\section{CONCLUSIONS}

AG, AV and Zn by virtue of their antioxidant properties, protect the liver and kidney from damages due to $\mathrm{Cd}$ more effectively in rats.

\section{KEY WORDS}

Cadmium, Zinc, Kidney, Liver, Apium graveolens, Aloe vera
Corresponding Author:

Dr. Sushanth N. K.,

Research Scholar,

Department of Research and

Development, Saveetha Institute of

Medical and Technical Sciences,

Thandalam - 602105, Chennai, India.

E-mail: sushanthanatomy.ss@outlook.com

DOI: $10.14260 / j e m d s / 2021 / 426$

How to Cite This Article:

Sushanth NK, Vijayaraghavan $R$, Vijayalakshmi $S$, et al. Comparison of protective effect of apium graveolens and aloe vera supplemented with zinc on cadmium induced hepato- and nephrotoxicity in wistar rats. J Evolution Med Dent Sci 2021;10(28):2083-2088, DOI: $10.14260 / \mathrm{jemds} / 2021 / 426$

Submission 29-01-2021,

Peer Review 12-05-2021,

Acceptance 18-05-2021,

Published 12-07-2021.

Copyright (c) 2021 Sushanth N.K. et al. This is an open access article distributed under Creative Commons Attribution License [Attribution 4.0 International (CC BY 4.0)] 


\section{BACKGROUND}

Cadmium (Cd) is a heavy metal and a well-known environmental toxicant. The major source of exposure is drinking water and food contaminated with $\mathrm{Cd} .{ }^{1}$ It could not be shown that $\mathrm{Cd}$ has any physiological role in human body. There are basically three ways of Cd resorption into the body: pulmonary, gastrointestinal and dermal. Majority of $\mathrm{Cd}$ that reaches blood, is transported bound to proteins. The first organ the $\mathrm{Cd}$ reaches is the liver, where it induces metallothionein production forming Cd-Metallothionein (Cd MT) complex. This causes hepatocyte necrosis and apoptosis. The Cd-MT complex reaches sinusoids, from where by absorption $\mathrm{Cd}$ enters enterohepatic cycle in the form of $\mathrm{Cd}$ glutathione conjugate. $\mathrm{Cd}$ then enters small intestine as $\mathrm{Cd}$ cysteine complexes following enzymatic degradation. ${ }^{2}$

For long term accumulation, Cd chooses kidney as main organ. ${ }^{3}$ Long term accumulation results in tubule cell necrosis. $\mathrm{Cd}$ reaches the kidney as Cd-MT, filtrated in the glomerulus and in the proximal convoluted tubules it is reabsorbed. $\mathrm{Cd}^{2+}$ ion has similarities, due to which it is likely to substitute $\mathrm{Ca}^{2+}$ and $\mathrm{Zn}^{2+}$ in various physiological processes resulting in activation and or inhibition of a number of important signaling pathways. Cd increases oxidative stress by binding to sulfhydryl groups of proteins and depleting glutathione, an antioxidant. ${ }^{4}$ Additionally, $\mathrm{Cd}$ exposure gives rise to generation of reactive oxygen species (ROS) and enhances lipid peroxidation leading to tissue damage. ${ }^{5}$

All organs contain an essential antioxidant trace element zinc (Zn) that is essential for cell proliferation, differentiation, and normal growth. It offers protection to tissues against free radicals and oxidative stress. ${ }^{6}$ It prevents cell damage by activation of antioxidant system.

The present study was to analyse and compare the protective effect of $\mathrm{AG}, \mathrm{AV}$ with and without $\mathrm{Zn}$ in Liver and Kidney of rats exposed to $\mathrm{Cd}$. Use of antioxidant properties of AG (commonly known as celery) against Cd induced pathology is not available in the literature.

\section{METHODS}

66 healthy adult male Wistar rats were obtained from Biogen, Bangalore. They were housed in cages at animal facility, Department of Research and Development, SIMATS, with natural light. These conditions were maintained throughout the experimental period. The animals weighing $200-250 \mathrm{~g}$ were randomly divided into the following 11 groups $(\mathrm{N}=6)$ after 4 days of acclimatisation.

1. Group 1: $1 \mathrm{ml}$ of $0.5 \% \mathrm{CMC}$ in distilled water.

2. Group 2: $10 \mathrm{mg} / \mathrm{kg}$ bw of $\mathrm{CdCl}_{2}$ in $0.5 \% \mathrm{CMC}$

3. Group 3: $10 \mathrm{mg} / \mathrm{kg}$ bw of $\mathrm{CdCl}_{2}+40 \mathrm{mg} / \mathrm{kg}$ bw of $\mathrm{ZnCl}_{2}$ in $0.5 \% \mathrm{CMC}$

4. Group 4: $10 \mathrm{mg} / \mathrm{kg}$ bw of $\mathrm{CdCl}_{2}+200 \mathrm{mg} / \mathrm{kg}$ bw of Aloe vera in $0.5 \% \mathrm{CMC}$

5. Group 5: $10 \mathrm{mg} / \mathrm{kg}$ bw of $\mathrm{CdCl}_{2}+400 \mathrm{mg} / \mathrm{kg}$ bw of Aloe vera in $0.5 \% \mathrm{CMC}$

6. Group 6: $10 \mathrm{mg} / \mathrm{kg}$ bw of $\mathrm{CdCl}_{2}+40 \mathrm{mg} / \mathrm{kg}$ bw of $\mathrm{ZnCl}_{2}$ $+200 \mathrm{mg} / \mathrm{kg}$ bw of Aloe vera in $0.5 \% \mathrm{CMC}$
7. Group 7: $10 \mathrm{mg} / \mathrm{kg}$ bw of $\mathrm{CdCl}_{2}+40 \mathrm{mg} / \mathrm{kg}$ bw of $\mathrm{ZnCl}_{2}$ $+400 \mathrm{mg} / \mathrm{kg}$ bw of Aloe vera in $0.5 \% \mathrm{CMC}$

8. Group 8: $10 \mathrm{mg} / \mathrm{kg}$ bw of $\mathrm{CdCl}_{2} 200 \mathrm{mg} / \mathrm{kg}$ bw of Apium graveolens in $0.5 \% \mathrm{CMC}$

9. Group 9: $10 \mathrm{mg} / \mathrm{kg}$ bw of $\mathrm{CdCl}_{2}+400 \mathrm{mg} / \mathrm{kg}$ bw of Apium graveolens in $0.5 \% \mathrm{CMC}$

10. Group 10: $10 \mathrm{mg} / \mathrm{kg}$ bw of $\mathrm{CdCl}_{2}+40 \mathrm{mg} / \mathrm{kg}$ bw of $\mathrm{ZnCl}_{2}$ $+200 \mathrm{mg} / \mathrm{kg}$ bw of Apium graveolens in $0.5 \% \mathrm{CMC}$

11. Group 11: $10 \mathrm{mg} / \mathrm{kg}$ bw of $\mathrm{CdCl}_{2}+40 \mathrm{mg} / \mathrm{kg}$ bw of $\mathrm{ZnCl}_{2}$ $+400 \mathrm{mg} / \mathrm{kg}$ bw of Apium graveolens in $0.5 \% \mathrm{CMC}$

The concentration and quantity of the dose / rat was calculated according to body weight and were administered orally using a gavage for 56 days. At the end of the treatment, animals were sacrificed, and liver and kidney were collected and preserved in $10 \%$ formalin for histopathological analysis.

\section{Histopathological Study}

The vital organs (Liver and Kidney) after isolation were fixed in $10 \%$ formalin and embedded in paraffin wax. Paraffin sections were made at $5 \mu \mathrm{m}$ and stained with haematoxylin and eosin (H\&E). The slides were studied under a light microscope.

\section{Statistical Analysis}

Sigma Plot 13.0 Systat software, USA was used for statistical analysis.

\section{RESULTS}

\section{Histopathology of Liver}

The liver of control group showed normal lobules, parenchyma, hepatic cords and sinusoids. The liver of $\mathrm{Cd}$ treated rats on light microscopic examination showed distorted architecture with shrunken and discontinuity of central vein along with degeneration of cells in the radiating cord of hepatocytes.

The portal triad accumulated collagen tissue around it and sinusoidal space was enlarged. Small nuclei with vacuolization of hepatocyte cytoplasm, rupture of cell membrane, infiltration of mononuclear cells in to the interstitium were observed. Intercellular necrotic gaps in the hepatic lobules, hepatocellular swelling and atrophy of hepatic portals were other noticeable features. The $\mathrm{Cd}+\mathrm{Zn}$ treated rats, showed near normal architecture with central vein and radiating hepatocytes with intact portal triad and normal sinusoidal space.

Similarly, the rats treated with Cd + AV200 and Cd + AG200 showed that the extracts were able to protect the tissue from $\mathrm{Cd}$ insult since the cellular architecture was preserved to a significant extent in them. However, Cd + AV400 and Cd + AG400 was not effective in maintaining the normal histology by protecting against $\mathrm{Cd}$.

Among the rats treated with $200 \mathrm{mg} / \mathrm{Kg}$ and $400 \mathrm{mg} / \mathrm{Kg}$ of $\mathrm{AV}$ and $\mathrm{AG}$ extracts in combination with $\mathrm{Zn}$, the $200 \mathrm{mg} / \mathrm{Kg}$ of both $\mathrm{AV}$ and $\mathrm{AG}$ showed significant protective properties against Cd unlike the $400 \mathrm{mg} / \mathrm{Kg}$ b.w. which were not equally effective. This protective nature of the extracts could be attributed to their antioxidant properties (Figure 1). 


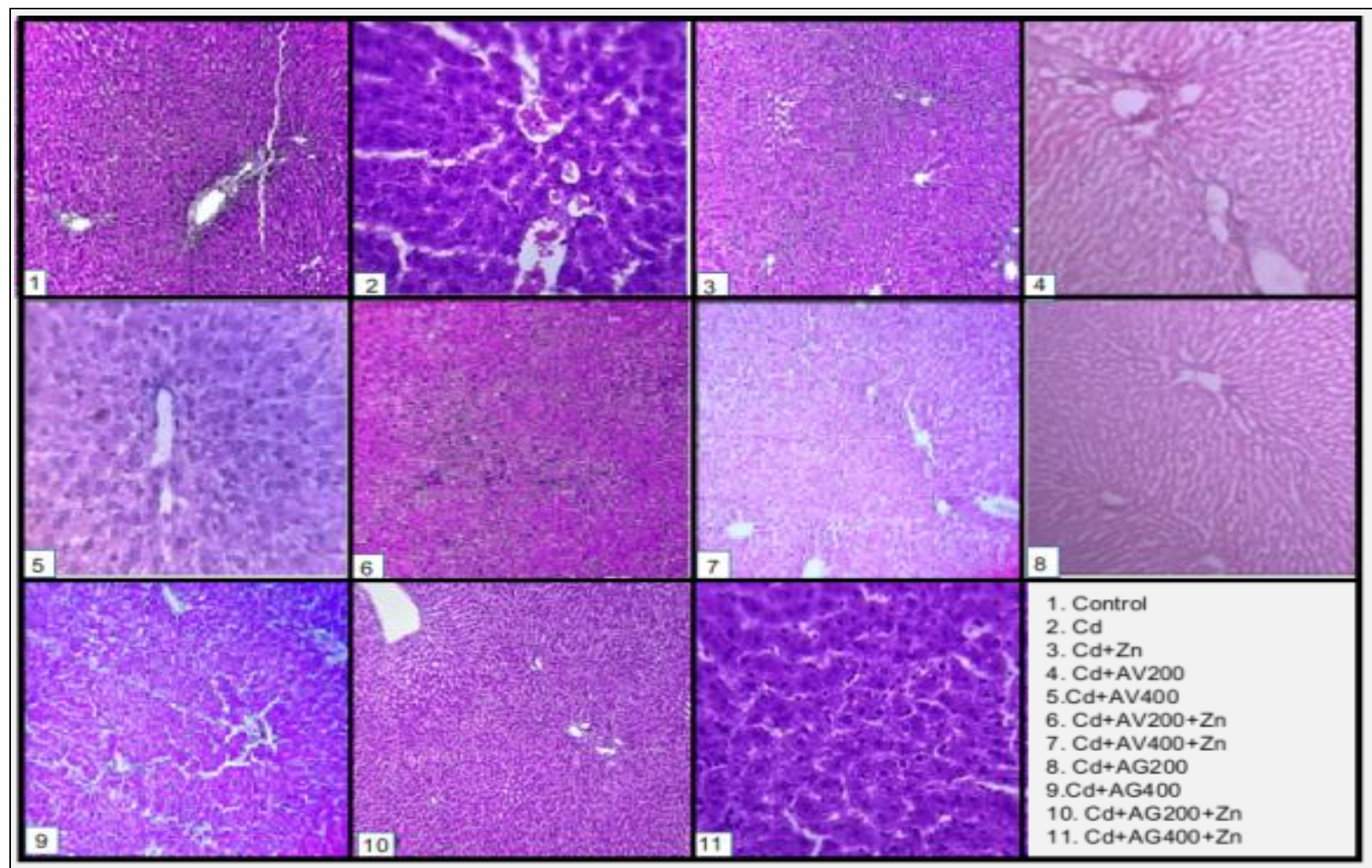

Figure 1. Photomicrograph of H \& E Stained Section of Liver (10X Magnification) in Cadmium (Cd, $10 \mathrm{mg} / \mathrm{kg}$, p.o.) Toxicity and Its Protection by Zinc (Zn, $40 \mathrm{mg} / \mathrm{kg}$, p.o.), Aloe Vera Extract (AV, 200 and $400 \mathrm{mg} / \mathrm{kg}$, p.o.), Apium Graveolens Extract ( $A G, 200$ and $400 \mathrm{mg} / \mathrm{kg}, \mathrm{p.o}$.) and Their Combinations ( $\mathrm{N}=6$ Each)

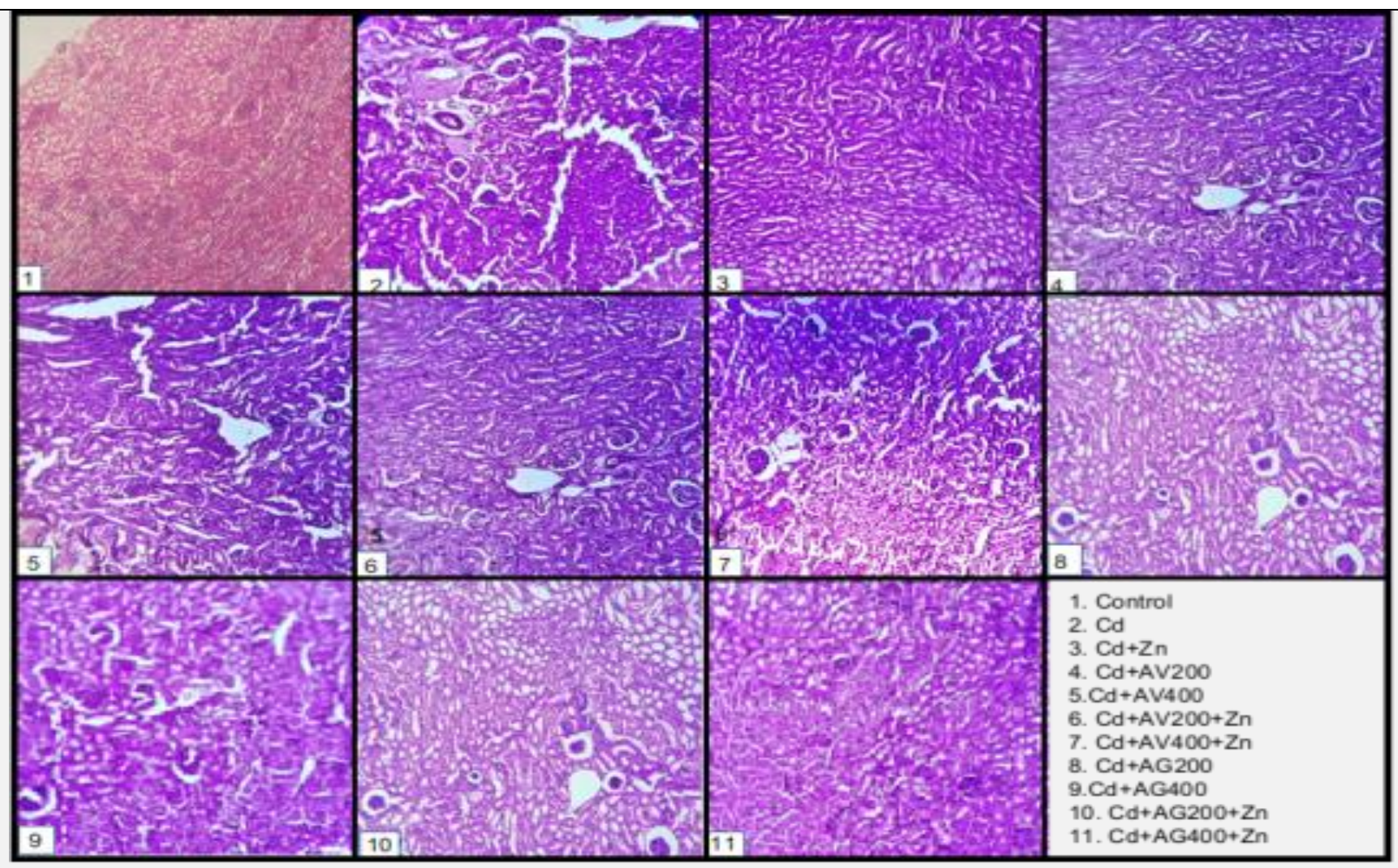

Figure 2. Figure 6.10: Photomicrograph of H \& E Stained Section of Kidney (10X Magnification) in Cadmium (Cd, 10 $\mathrm{mg} / \mathrm{kg}$, p.o.) Toxicity and Its Protection by Zinc (Zn, $40 \mathrm{mg} / \mathrm{kg}$, p.o.), Aloe Vera Extract (AV, 200 and $400 \mathrm{mg} / \mathrm{kg}$, p.o.), Apium graveolens Extract (AG, 200 and $400 \mathrm{mg} / \mathrm{kg}$, p.o.) and Their Combinations ( $N=6$ Each) 
Photomicrograph of $\mathrm{H} \& \mathrm{E}$ stained section of liver in cadmium (Cd, $10 \mathrm{mg} / \mathrm{kg}$, p.o.) toxicity and its protection by zinc (Zn, $40 \mathrm{mg} / \mathrm{kg}$, p.o.), Aloe vera extract (AV, 200 and 400 $\mathrm{mg} / \mathrm{kg}$, p.o.), Apium graveolens extract (AG, 200 and $400 \mathrm{mg}$ / $\mathrm{kg}$, p.o.) and their combinations.

\section{Histopathology of Kidney}

On light microscopic examination, the kidney of control rats showed normal cortex and medulla regions with normal PCT, DCT, renal corpuscles, collecting duct and Henle's loop. Renal parenchyma, epithelium of the tubules, nuclei of the epithelial cells, glomeruli with the capillary, endothelial cells and mesangium all appeared normal. Cd treated rats showed abnormal architecture with the epithelial lining of proximal and distal convoluted tubules thinned out, shrunken and distorted lumen, degenerated glomeruli and reduced vascularity. The kidney tissue appeared pale, with tissue lesions in the cortex and medulla with visible necrosis. Massive local haemorrhage and destructed basement membrane were noted. Some abnormal renal structures, thin epithelial layer and irregular tubule lumen were observed. Severe necrosis and degeneration were noticed in some regions of the cortex associated with degenerated tubules, glomeruli and overall a compromised cellular integrity was observed. The $\mathrm{Cd}+\mathrm{Zn}$ treated rats, showed near normal architecture with mostly intact glomeruli, proximal and distal convoluted tubules. Cd + AV200 and Cd + AG200 treated rats showed that the extracts were able to protect the cellular architecture to a significant extent by preventing toxic effects of Cd largely due to their antioxidant properties. In Cd + AV400 and Cd + AG400 treated groups, the dose of $400 \mathrm{mg} / \mathrm{Kg}$ b.w was not as effective as $200 \mathrm{mg} / \mathrm{kg}$ b.w in maintaining the normal histology by protecting against $\mathrm{Cd}$. Among the rats which were treated with $200 \mathrm{mg} / \mathrm{Kg}$ and $400 \mathrm{mg} / \mathrm{Kg}$ b.w of hydroalcoholic extracts of AV and AG in combination with $\mathrm{Zn}$, the dose of $200 \mathrm{mg} / \mathrm{Kg}$ b.w of both the extracts showed significant protective properties against $\mathrm{Cd}$ unlike the dose $400 \mathrm{mg} / \mathrm{Kg}$ b.w which were less effective (Figure 2).

Figure 2 Photomicrograph of H\&E stained section of kidney in cadmium (Cd, $10 \mathrm{mg} / \mathrm{kg}$, p.o.) toxicity and its protection by zinc ( $\mathrm{Zn}, 40 \mathrm{mg} / \mathrm{kg}$, p.o.), Aloe vera extract (AV, 200 and $400 \mathrm{mg} / \mathrm{kg}$, p.o.), Apium graveolens extract (AG, 200 and $400 \mathrm{mg} / \mathrm{kg}$, p.o.) and their combinations.

\section{DISCUSSION}

Cd causes injury to several tissues, including liver and kidney. ${ }^{7}$ $\mathrm{Cd}$ is an exceptionally poisonous metal that is extremely harmful to people because its accumulation in tissues causes metabolic, histological, and pathological changes. ${ }^{8}$ The Kupffer cells (KC) in liver can directly damage its cells by releasing wide variety of cytotoxic mediators that include reactive oxygen species (ROS), nitric oxide (NO), and cytotoxic proteins. Apart from these, KC promote infiltration of other inflammatory cells by releasing chemokines into the liver. ${ }^{9} \mathrm{~A}$ large number of ROS are released by infiltrating neutrophils. This results in oxidative stress and lipid peroxidation (LPO). ${ }^{10}$
There are evidences suggesting direct hepatocyte damage due to Cd. Additionally, new evidences suggest that ischemia may also play a role in $\mathrm{Cd}$ - induced liver injury. ${ }^{11}$ Ischemia that occurs due to liver damage may result from direct effects of $\mathrm{Cd}$ on hepatic EC. The damaged cells that enter the sinusoidal space alter hepatic microcirculation and cause hypoxia that further makes hepatocytes more prone for harmful effects due to Cd. ${ }^{12}$ The hepatocyte damage was evident in $\mathrm{H} \& \mathrm{E}$ stained sections of the liver tissue of rats in Cd group in the present study. In general, $\mathrm{Cd}$ induced oxidative stress plays a major role in inducing toxicities in kidney, liver and testes. ${ }^{13}$

In the present study, alterations observed in normal histology of kidney was due to cadmium induced toxicities. The major pathological changes observed were damage of tubule epithelium and surrounding blood vessels, increase in interstitial space due to loss of connective tissue integrity, glomerular lesion involving the epithelial cells and the capillary loop. So, it is evident that microvascular damages have also taken place. Aughey ${ }^{14}$ and Mitsumori ${ }^{15}$ reported similar or more advanced changes in liver and kidney histology and functions under the influence of $\mathrm{Cd}$.

$\mathrm{Zn}$ exhibits its protective effect in Cd exposed rats in various organs and tissues. ${ }^{16,17} \mathrm{Zn}$ protects renal tissues against the toxicity of $\mathrm{Cd} .{ }^{18}$ Similar result was obtained in the present study also. It could be due to the protective nature of Zn by acting as an antioxidant.19,20,21 Furthermore, Zn supplementation prevents increased rate of lipid peroxidation. ${ }^{22}$ It was found that when $\mathrm{Cd}$ was given in combination with $\mathrm{Zn}$ simultaneously, the protective effect of Zn was exhibited clearly, and the toxicity caused was less when Cd was administered alone. ${ }^{23}$ Similar results were found in the present study.

The $\mathrm{Cd}$ treated rats in their liver showed several degenerative changes and these findings of the present study were in agreement with the previous studies. ${ }^{24,25,26}$ Also subchronic exposure with $\mathrm{CdCl}_{2}$ caused liver damage, demonstrated by histopathological alterations; moderate degeneration (ballooning) and discrete necrosis. ${ }^{27}$

The histopathological changes in liver could be because of the highly reactive radicals and the lipid peroxidation that results following it due to $\mathrm{Cd}$. The accumulated hydroperoxidase can cause cytotoxicity, which is associated with the peroxidation of membrane phospholipids by lipid hydroperoxidase, the basis for hepatocellular damage. ${ }^{26}$

The histopathological changes observed in the kidney of Cd treated rats in the present study is in accordance with a study ${ }^{28}$ which found that $\mathrm{Cd}$ affected the glomeruli especially glomerular capillaries in Bowman's space and atrophy of some glomerulus.

Several histopathological studies revealed the toxic effect of $\mathrm{Cd}$ in the kidney and one such change was proximal tubular necrosis, apoptosis, and tubular degeneration. ${ }^{29}$

Tubular necrosis and degeneration was found in this study also. These changes could be due to the accumulation of free radicals as a consequence of increased lipid peroxidation by free $\mathrm{Cd}$ ions in the renal tissues of $\mathrm{Cd}$ - treated rats. ${ }^{26}$

The kidney and liver treated with hydroalcoholic extracts of $\mathrm{AV}$ and $\mathrm{AG}$ showed minimal histopathological changes especially at the dose of $200 \mathrm{mg} / \mathrm{Kg}$ than $400 \mathrm{mg} / \mathrm{Kg}$ bw. Both these plants are rich in antioxidants (such as vitamin $\mathrm{C}$ ) and antioxidants counter the deleterious effects of ROS that 
were generated in this case due to $\mathrm{Cd}$. Earlier studies on the beneficial role of vitamin $\mathrm{C}$ on $\mathrm{Cd}$ - induced organ toxicity reported that antioxidant supplements with vitamin $\mathrm{C}$ have a prophylactic effect. ${ }^{30}$

$\mathrm{Zn}$ is an essential component of the oxidant defense system with participation at multiple cellular levels. ${ }^{31}$

In the present work, treatment with $\mathrm{Cd}$ and $\mathrm{Zn}$ effectively protected liver and kidney against $\mathrm{Cd}$ - induced damage. $\mathrm{Zn}$ has a protective effect on histological damage by maintaining membrane integrity due to its direct action on free radicals. ${ }^{32}$ When the extracts were supplemented with $\mathrm{Zn}$, due to the combined actions of $\mathrm{Zn}$ and antioxidants in the extracts, they were able to very effectively protect the tissues from damages due to Cd. On comparison, AG at the dose of $200 \mathrm{mg} / \mathrm{kg}$ bw was better protective than $200 \mathrm{mg} / \mathrm{Kg}$ bw of AV. With Zn supplementation the protective nature was enhanced.

\section{CONCLUSIONS}

The Cd is, very much a potential threat to biological system. $\mathrm{Zn}$ acts as a chelator and antioxidant and is capable of maintaining structural and functional integrity of tissues. Among antioxidant rich $\mathrm{AG}$ and $\mathrm{AV}, \mathrm{AG}$ offers better protection against pathological effects of $\mathrm{Cd}$ in combination with $\mathrm{Zn}$ without any side effects.

Data sharing statement provided by the authors is available with the full text of this article at jemds.com.

Financial or other competing interests: None.

Disclosure forms provided by the authors are available with the full text of this article at jemds.com.

\section{REFERENCES}

[1] World Health Organization. Air quality Guidelines. Cadmium. Copenhagen, Denmark: Regional Office for Europe 2000.

[2] Zalups RK, Ahmad S. Molecular handling of cadmium in transporting epithelia. Toxicol Appl Pharmacol 2003;186(3):163-88.

[3] Orlowski C, Piotrowski JK. Biological levels of cadmium and zinc in the small intestine of non-occupationally exposed human subjects. Hum Exp Toxicol 2003;22(2):57-63.

[4] Valko M, Morris H, Cronin MT. Metals, toxicity and oxidative stress. Curr Med Chem 2005;12(10):1161-208.

[5] Gupta RS, Gupta ES, Dhakal BK, et al. Vitamin E protect the rat testes from cadmium-induced reactive oxygen species. Mol Cells 2004;17(1):132-9.

[6] Afonne OJ, Orisakwe OE, Ekanem IA. Zinc protects chromium induced testicular injury in mice. Indian J Pharmacol 2002;34(1):26-31.

[7] Dudley RE, Svoboda DJ, Klaassen C. Acute exposure to cadmium causes severe liver injury in rats. Toxicol Appl Pharmacol 1982;65(2):302-13.

[8] Stajn A, Zikić RV, Ognjanović B, et al. Effect of cadmium and selenium on the antioxidant defense system in rat kidneys. Comp Biochem Physiol C Pharmacol Toxicol Endocrinol 1997;117(2):167-72.
[9] Laskin DL, Pilaro AM, Ji S. Potential role of activated macrophages in acetaminophen hepatotoxicity. II. Mechanism of macrophage accumulation and activation. Toxicol Appl Pharmacol 1986;86(2):216-26.

[10] Manca D, Ricard AC, Trottier B, et al. Studies on lipid peroxidation in rat tissues following administration of low and moderate doses of cadmium chloride. Toxicology 1991;67(3):303-23.

[11] Liu J, Kershaw WC, Liu YP, et al. Cadmium-induced hepatic endothelial cell injury in inbred strains of mice. Toxicology 1992;75(1):51-62.

[12] Rikans LE, Yamano T. Mechanisms of cadmium-mediated acute hepatotoxicity. J Biochem Mol Toxicol 2000;14(2):110-17.

[13] Morales AI, Vicente-Sánchez C, Sandoval JM, et al. Protective effect of quercetin on experimental chronic cadmium nephrotoxicity in rats is based on its antioxidant properties. Food Chem Toxicol 2006;44(12):2092-100.

[14] Aughey E, Fell GS, Scott R, et al. Histopathology of early effects of oral cadmium in the rat kidney. Environ Health Perspect 1984;54:153-61.

[15] Mitsumori K, Shibutani S, Sato S, et al. Relationship between the development of hepatorenal toxicity and cadmium accumulation in rats given minimum to large amounts of cadmium chloride in the long term: preliminary study. Arch Toxicol 1998;72(9):545-52.

[16] Chowdhury BA, Friel JK, Chandra RK. Cadmium-induced immunopathology is prevented by zinc administration in mice. J Nutr 1987;117(10):1788-94.

[17] Jemai H, Messaoudi I, Chaouch A, et al. Protective effect of zinc supplementation on blood antioxidant defense system in rats exposed to cadmium. J Trace Elem Med Biol 2007;21(4):269-73.

[18] Jacquillet G, Barbier 0, Cougnon M, et al. Zinc protects renal function during cadmium intoxication in the rat. Am J Physiol Renal Physiol 2006;290(1):127-37.

[19] Hu Y, Jin T, Zhou T, et al. Effects of zinc on gene expressions induced by cadmium in prostate and testes of rats. Biometals 2004;17(5):571-2.

[20] Kara H, Cervik A, Konar V, et al. Protective effects of antioxidants against cadmium induced oxidative damage in rat testes. Biol Trace Elem Res 2007;120(1-3):205-11.

[21] Amara S, Abdelmelek H, Garrel C, et al. Preventive effect of zinc against cadmium-induced oxidative stress in the rat testis. J Reprod Dev 2008;54(2):129-34.

[22] Shaheen AA, El-Fattah AA. Effect of dietary zinc on lipid peroxidation, glutathione, protein levels and superoxide dismutase activity in rat tissues. Int J Biochem Cell Biol 1995;27(1):89-95.

[23] Gunn S, Gould TM, Andersson WA. Zinc protection against cadmium injury to rat testis. Arch Pathol 1961;71:274-81.

[24] Gong P, Chen FX, Ma GF, et al. Endomorphin 1 effectively protects cadmium chloride-induced hepatic damage in mice. Toxicology 2008;251(1-3):35-44.

[25] Ersan Y, Ari I, Koc E. Effect of cadmium compounds (cadmium para hydroxybenzoate and cadmium chloride) on the liver of mature mice. Turk J Zool 2008;32(2):1159.

[26] Renugadevi J, Prabu SM. Cadmium-induced hepatotoxicity in rats and the protective effect of naringenin. Exp Toxicol Pathol 2010;62(2):171-81.

[27] Borges LP, Brandao R, Godi B, et al. Oral administration of diphenyl diselenide protects against cadmium-induced 
liver damage in rats. Chem Biol Interact 2008;171(1):1525.

[28] Jemai H, Lachkar HA, Messaoudi I, et al. Effect of zinc pretreatment on blood glutathione, serum zinc and kidney histological organization in male rats exposed to cadmium. J Trace Elem Med Biol 2010;24(4):277-88.

[29] Damek-Poprawa M, Sawicka-Kapusta K. Histopathological changes in the liver, kidney and testes of bank voles environmentally exposed to heavy metal emissions from the steelworks and zinc smelter in Poland. Environ Res 2004;96(1):72-8.
[30] Koyuturk M, Yanardag R, Bolkent S, et al. The potential role of combined antioxidant against cadmium toxicity on liver of rats. Toxicol Ind Health 2007;23(7):393-401.

[31] Bray TM, Bettger WJ. The physiological role of zinc as an antioxidant. Free Radic Biol Med 1990;8(3):281-91.

[32] Liu XY, Jin TY, Nordberg GF, et al. Multivariate study of protective effects of $\mathrm{zn}$ and $\mathrm{cu}$ against nephrotoxicity induced by cadmium metallothionein in rats. Toxicol Appl Pharmacol 1998;151(2):276-82. 